\title{
Updates to the Suspended Sediment SPARROW Model Developed for Western Oregon and Northwestern California
}

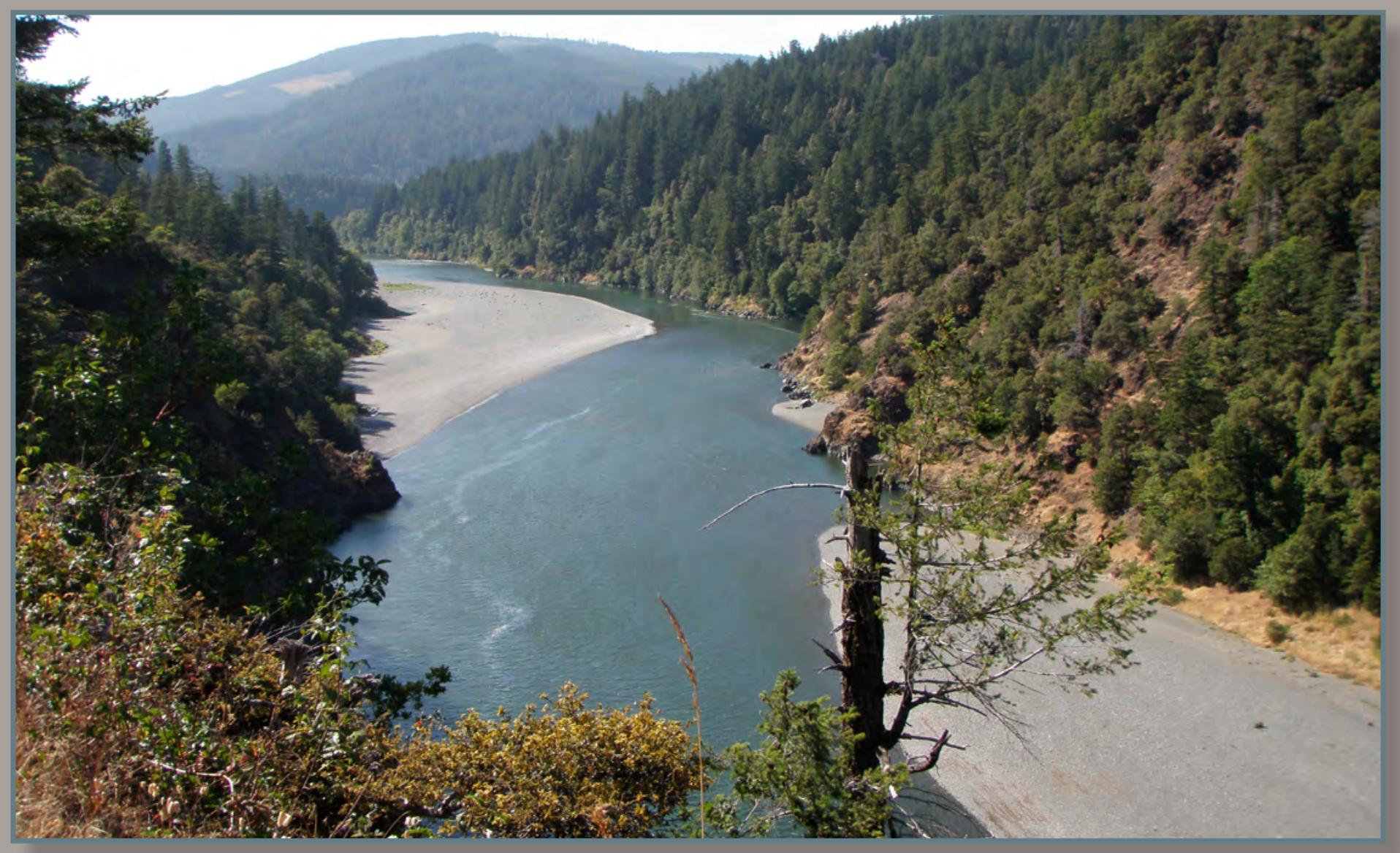

Scientific Investigations Report 2018-5156

U.S. Department of the Interior

U.S. Geological Survey 
Cover: Photograph showing Rogue River near Agnes, Oregon, looking downstream. Photograph by Joseph Mangano, U.S. Geological Survey, July 27, 2010. 


\section{Updates to the Suspended Sediment SPARROW Model Developed for Western Oregon and Northwestern California}

By Daniel R. Wise

Scientific Investigations Report 2018-5156 


\section{U.S. Department of the Interior RYAN K. ZINKE, Secretary}

\section{U.S. Geological Survey James F. Reilly II, Director}

\section{U.S. Geological Survey, Reston, Virginia: 2018}

For more information on the USGS - the Federal source for science about the Earth, its natural and living resources, natural hazards, and the environment-visit https://www.usgs.gov or call 1-888-ASK-USGS.

For an overview of USGS information products, including maps, imagery, and publications, visit https://store.usgs.gov.

Any use of trade, firm, or product names is for descriptive purposes only and does not imply endorsement by the U.S. Government.

Although this information product, for the most part, is in the public domain, it also may contain copyrighted materials as noted in the text. Permission to reproduce copyrighted items must be secured from the copyright owner.

Suggested citation:

Wise, D.R., 2018, Updates to the suspended sediment SPARROW model developed for western Oregon and northeastern California: U.S. Geological Survey Scientific Investigations Report 2018-5156, 23 p., https://doi. org/10.3133/sir20185156.

ISSN 2328-0328 (online) 


\section{Contents}

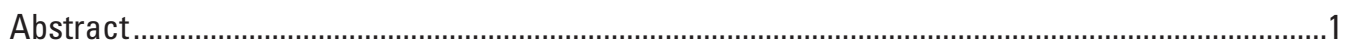

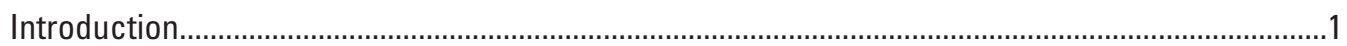

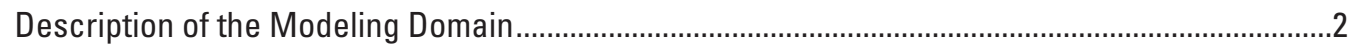

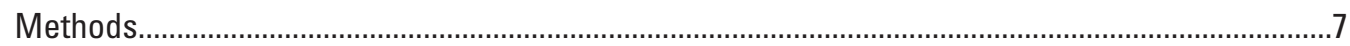

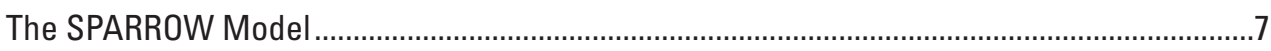

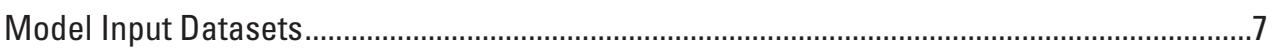

Surface-Water Drainage Network.................................................................................

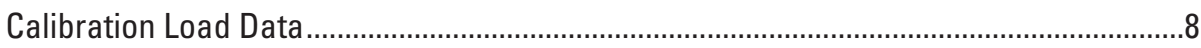

Catchment Attribute Data...............................................................................................

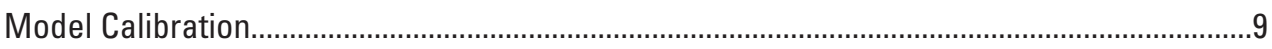

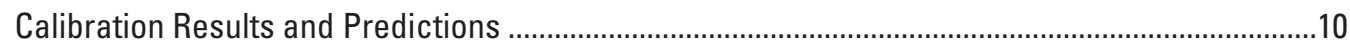

Interpretation of Results from the Updated SPARROW Suspended Sediment Models ..................20

Differences Between the Original and Updated Suspended Sediment SPARROW Models ..........20

Application of the Updated Suspended Sediment SPARROW Models ............................................20

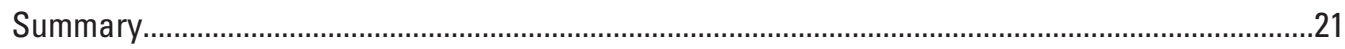

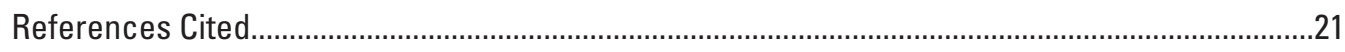

Appendix 1. Summary of Calibration Data for the Updated Suspended Sediment SPARROW

Models Developed for Western Oregon and Northwestern California................................23

\section{Figures}

1. Maps showing major watersheds $(A)$ and generalized land cover $(B)$ within the modeling domain for the suspended sediment SPARROW models for western Oregon and northwestern California

2. Map showing generalized lithologic provinces within the modeling domain for the suspended sediment SPARROW models for western Oregon and northwestern California

3. Map showing mean annual precipitation within the modeling domain for the suspended sediment SPARROW models for western Oregon and northwestern California

4. Map showing the studentized residuals for the updated lithology-based suspended sediment SPARROW model for western Oregon and northwestern California

5. Map showing the studentized residuals for the updated land-cover based suspended sediment SPARROW model for western Oregon and northwestern California

6. Map showing incremental suspended-sediment yields predicted by the updated lithology-based suspended sediment SPARROW model for western Oregon and northwestern California.

7. Map showing the contribution from selected watersheds to the estimated suspended-sediment load delivered to the Willamette River near Portland, Oregon, as predicted by the updated lithology-based suspended sediment SPARROW model for western Oregon and northwestern California 


\section{Tables}

1. Potential explanatory variables evaluated in the updated suspended sediment SPARROW models for western Oregon and northwestern California

2. Description of lithologic provinces evaluated as sources in the updated suspended sediment SPARROW models for western Oregon and northwestern California

3. Description of generalized land-cover classes evaluated as sources in the updated suspended sediment SPARROW models for western Oregon and northwestern California

4. Calibration results from the updated lithology-based suspended sediment SPARROW model for western Oregon and northwestern California

5. Calibration results from the updated land-cover based suspended sediment SPARROW model for western Oregon and northwestern California

6. Summary statistics for incremental loads simulated by the updated suspended sediment SPARROW models for western Oregon and northwestern California

7. Summary of calibration results for the original and updated suspended sediment SPARROW models for western Oregon and northwestern California

8. Median incremental yields and flow-weighted concentrations predicted by the original and updated suspended sediment SPARROW models for western Oregon and northwestern California

9. Suspended-sediment conditions in the lower Willamette River, Oregon, as predicted by the updated suspended sediment SPARROW models for western Oregon and northwestern California.

10. Contribution from selected watersheds to the estimated suspended-sediment load delivered to the Willamette River near Portland, Oregon, as predicted by the updated suspended sediment SPARROW models for western Oregon and northwestern California 


\section{Conversion Factors}

International System of Units to U.S. customary units

\begin{tabular}{lll}
\hline \multicolumn{1}{c}{ Multiply } & \multicolumn{1}{c}{ By } & \multicolumn{1}{c}{ To obtain } \\
\hline centimeter $(\mathrm{cm})$ & Length & \\
meter $(\mathrm{m})$ & 0.3937 & inch (in.) \\
kilometer $(\mathrm{km})$ & 3.281 & foot $(\mathrm{ft})$ \\
& 0.6214 & mile $(\mathrm{mi})$ \\
\hline square kilometer $\left(\mathrm{km}^{2}\right)$ & Area & \\
square kilometer $\left(\mathrm{km}^{2}\right)$ & 247.1 & acre \\
\hline & 0.3861 & square mile $\left(\mathrm{mi}^{2}\right)$ \\
\hline cubic meter per second $\left(\mathrm{m}^{3} / \mathrm{s}\right)$ & Flow rate & \\
meter per day $(\mathrm{m} / \mathrm{d})$ & 35.32 & cubic foot per second $(\mathrm{ft} / \mathrm{s})$ \\
metric ton per year $(\mathrm{t} / \mathrm{yr})$ & 3.281 & foot per day $(\mathrm{ft} / \mathrm{d})$ \\
millimeter per year $(\mathrm{mm} / \mathrm{yr})$ & 0.9842 & short ton per year $(\mathrm{t} / \mathrm{yr})$ \\
\hline & 0.03937 & inch per year $(\mathrm{in} / \mathrm{yr})$ \\
\hline kilogram per square kilometer per year & Mass & \\
$\quad\left(\left[\mathrm{kg} / \mathrm{km}{ }^{2}\right] / \mathrm{yr}\right)$ & 5.71 & pound per square $\mathrm{mile} \mathrm{per} \mathrm{year}$ \\
metric ton $(\mathrm{t})$ & & $\left(\left[1 \mathrm{~b} / \mathrm{mi}{ }^{2}\right] / \mathrm{yr}\right)$ \\
\hline & 1.102 & ton, short $[2,000 \mathrm{lb}]$ \\
\hline kilogram per hectare per year $([\mathrm{kg} / \mathrm{ha}] / \mathrm{yr})$ & 0.8921 & pound per acre per year $([\mathrm{lb} / \mathrm{acre}] / \mathrm{yr})$ \\
\hline
\end{tabular}

\section{Datum}

Horizontal coordinate information is referenced to the North American Datum of 1983 (NAD 83).

Altitude, as used in this report, refers to distance above the vertical datum.

\section{Abbreviations}

$\begin{array}{ll}\text { NLLS } & \text { nonlinear least squares regression } \\ \text { RMSE } & \text { root mean squared error } \\ \text { SPARROW } & \text { SPAtially Related Regressions On Watershed attributes } \\ \text { SSC } & \text { suspended-sediment concentration } \\ \text { TMDL } & \text { total maximum daily load } \\ \text { TSS } & \text { total suspended solids } \\ \text { USGS } & \text { U.S. Geological Survey }\end{array}$





\title{
Updates to the Suspended Sediment SPARROW Model Developed for Western Oregon and Northwestern California
}

\author{
By Daniel R. Wise
}

\section{Abstract}

A SPARROW (SPAtially Related Regressions On Watershed attributes) model that was previously developed for western Oregon and northwestern California was updated using advancements in the SPARROW software and refinements to the input data. As was the case for the original model calibration, the updated models used the NHD Plus Version 2 as a hydrologic framework and relied on the same estimates of long-term mean suspended-sediment loads and watershed attributes. The updated calibration results indicated that two different SPARROW models were possible - one model from which sediment sources were represented by local lithology and one from which sediment sources were represented by generalized land-cover classes; precipitation, catchment slope, wildfire disturbance, and sediment loss in impoundments were significantly correlated with suspendedsediment loads in both models. The updated models also included a method to compensate for the bias introduced by using total suspended solids to represent suspended sediment in the calibration dataset - a feature that was not available during the original model calibration. The effect of this feature was an overall increase in estimated suspendedsediment loads. Although the lithology- and the land-cover based models used different landscape properties to describe sediment sources, each could be useful in specific applications. The lithology-based model provides more accurate estimates of suspended-sediment load, but the land-cover based model allows water-quality managers to estimate how much in-stream suspended-sediment load originates in areas with extensive development compared to the load that originates in areas with relatively little human impact.

\section{Introduction}

Suspended sediment is particulate organic and inorganic matter mixed into the water column and transported by streams and rivers. Suspended sediment is a natural consequence of streams and rivers draining landscapes, particularly those that are eroding because of land use or topography, but its presence in streams and rivers also results from bank erosion and abrasion of bed material and bedrock within channels. Suspended sediment, where deposited, builds landforms and habitats in floodplains, rivers, estuaries, and beaches. High levels of suspended sediment, however, can adversely affect water quality and in-stream biota by suppressing aquatic plant growth by reducing light penetration, abrading and clogging fish gills, and transporting compounds such as toxic chemicals and nutrients (Griffiths and Walton, 1978). High levels of suspended sediment also can adversely affect public water supplies (Morris and Fan, 1998).

Knowledge of in-stream suspended-sediment loads, therefore, is important to understanding landscape evolution and river behavior and for habitat and water-quality management. Because of its potential adverse effects on aquatic habitats, sediment often is addressed in total maximum daily load (TMDL) assessments. For example, the Oregon Department of Environmental Quality lists 46 waterbodies in western Oregon and the Klamath River Basin as "water quality limited" because of sedimentation or turbidity (Oregon Department of Environmental Quality, 2015a). A SPARROW (SPAtially Related Regressions On Watershed attributes) model was previously developed for western Oregon and 
northwestern California (Wise and O'Connor, 2016; referred to in this report as the original SPARROW model), and this model was recalibrated using advancements in the SPARROW software and refinements to the input data.

This report describes how the original SPARROW model was updated to determine the primary factors that control the generation and transport of suspended sediment in western Oregon and northwestern California. The objectives of the study were to use the updated models to estimate mean annual suspended-sediment loads in monitored and unmonitored stream reaches throughout the modeling domain and to quantify the relative contribution of different suspended sediment sources to in-stream suspended-sediment loads.

\section{Description of the Modeling Domain}

The domain for this modeling study encompassed $118,00 \mathrm{~km}^{2}-76$ percent in western Oregon and 24 percent in northwestern California. The calibration domain included the western slopes of the Cascade Range, the Oregon Coast Range, the intervening Willamette Valley, and parts of the Klamath and Siskiyou Mountains of northwestern California and southern Oregon. The major watersheds in the modeling domain were the Klamath River Basin (35 percent of the modeling domain), the southern Oregon coastal drainages (27 percent), the Willamette River Basin ( 25 percent), the northern Oregon coastal drainages (10 percent), the Smith River Basin (1.8 percent), and some drainages in the lower Columbia River Basin that were not included in the original SPARROW model (1.3 percent; fig. $1 A$ ). The dominant types of land cover in 2011 were forest land (59 percent of modeling domain) and scrub, shrub, and grass land (24 percent), with smaller areas of agricultural land ( 8.5 percent) and developed land (4.6 percent) (fig. $1 B$; Homer and others, 2012). The geology consists of Tertiary volcanic rocks of the Western and High Cascades (35 percent of modeling domain) which flank the young Quaternary volcanic rocks that form the modern volcanic arc of the Cascade Range, the Paleozoic and Mesozoic rocks of the tectonically accreted Klamath terrane (27 percent), the Tertiary volcanic and sedimentary rocks within the Coast Range (21 percent), and unconsolidated Quaternary sediment (17 percent) (fig. 2; O'Connor and others, 2014). Mean annual precipitation varies widely within the modeling domain, averaging more than 4,000 millimeters per year $(\mathrm{mm} / \mathrm{yr})$ in the northern and southern Oregon coastal drainages, to less than $600 \mathrm{~mm} / \mathrm{yr}$ within the Klamath River Basin (fig. 3). 


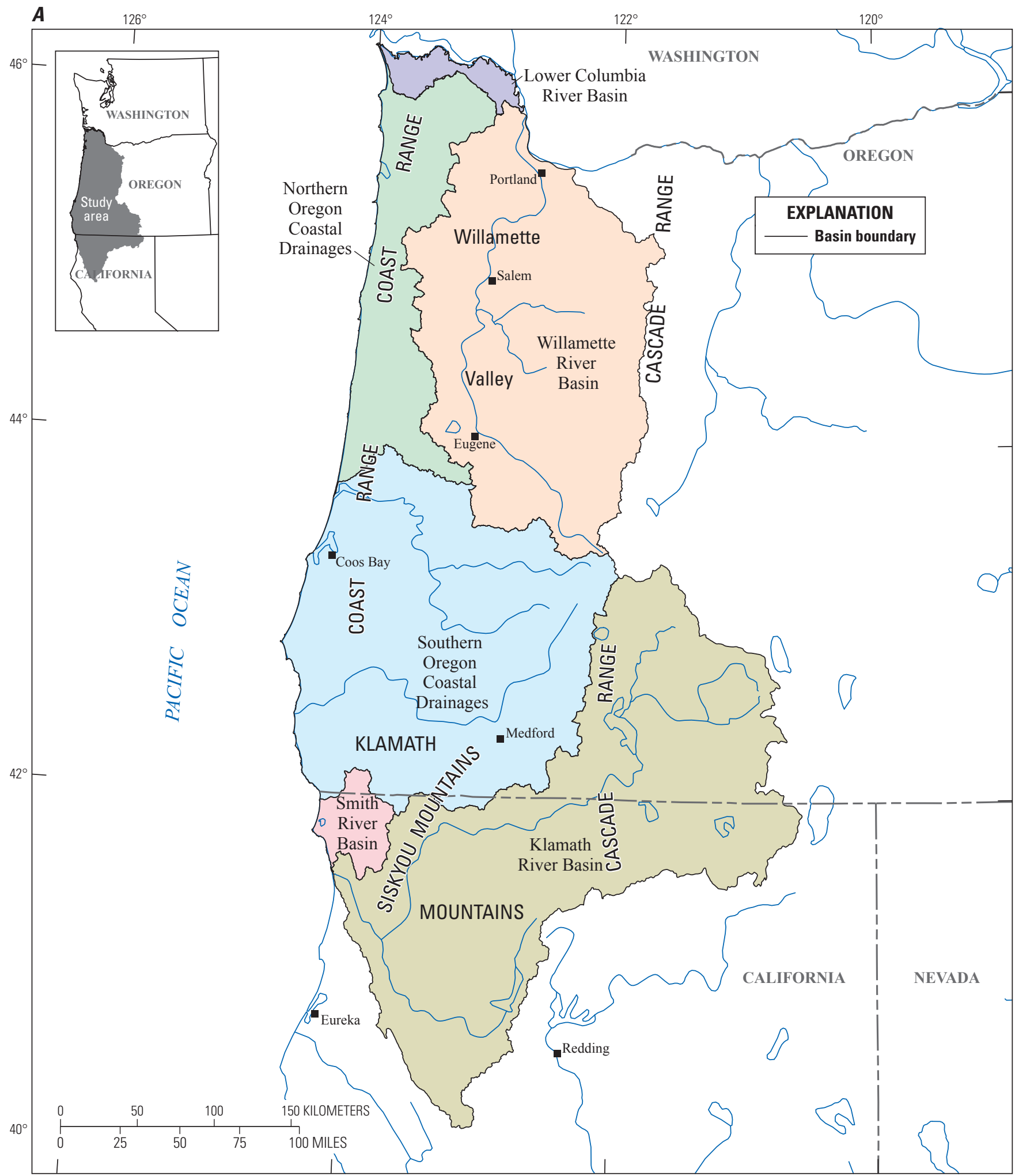

Base map modified from USGS and other digital data, various scales. Coordinate system: State Plane

Oregon North FIPS 3601. Horizontal datum: North American Datum of 1983 (HARN)

Figure 1. Major watersheds $(A)$ and generalized land cover $(B)$ within the modeling domain for the suspended sediment SPARROW models for western Oregon and northwestern California. 


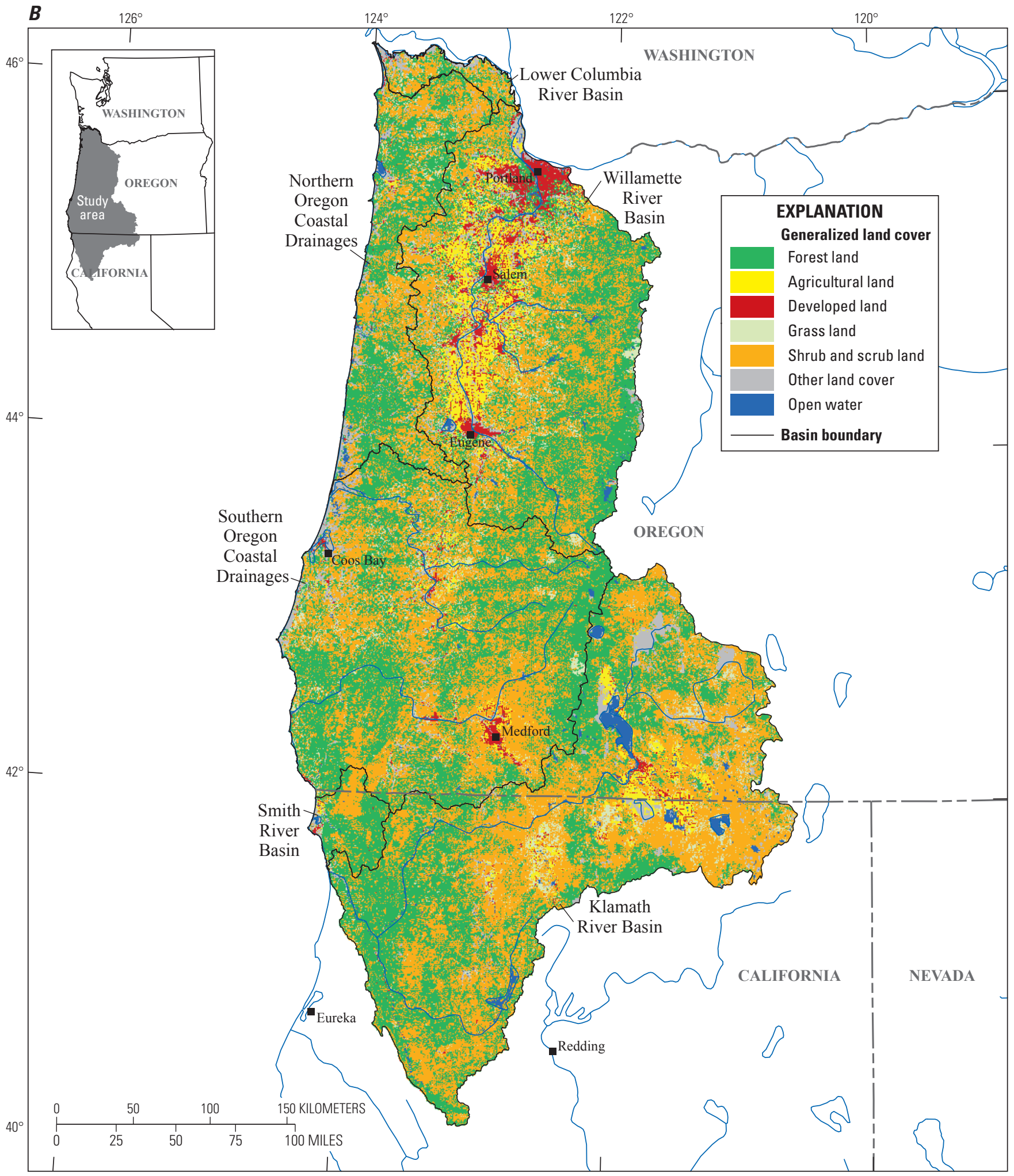

Base map modified from USGS and other digital data, various scales. Coordinate system: State Plane Oregon North FIPS 3601. Horizontal datum: North American Datum of 1983 (HARN)

Figure 1.-Continued 


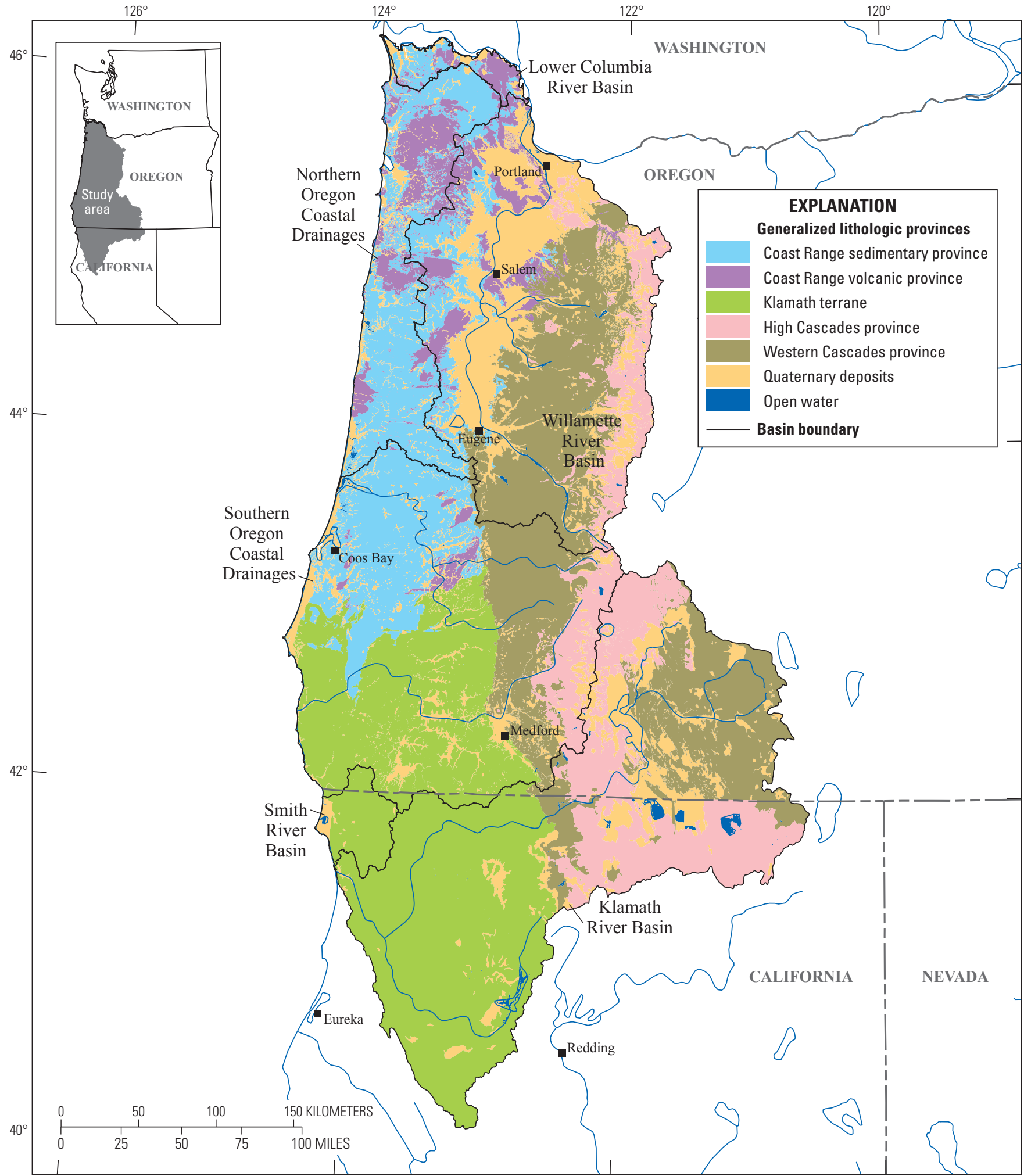

Base map modified from USGS and other digital data, various scales. Coordinate system: State Plane Oregon North FIPS 3601. Horizontal datum: North American Datum of 1983 (HARN)

Figure 2. Generalized lithologic provinces within the modeling domain for the suspended sediment SPARROW models for western Oregon and northwestern California. 


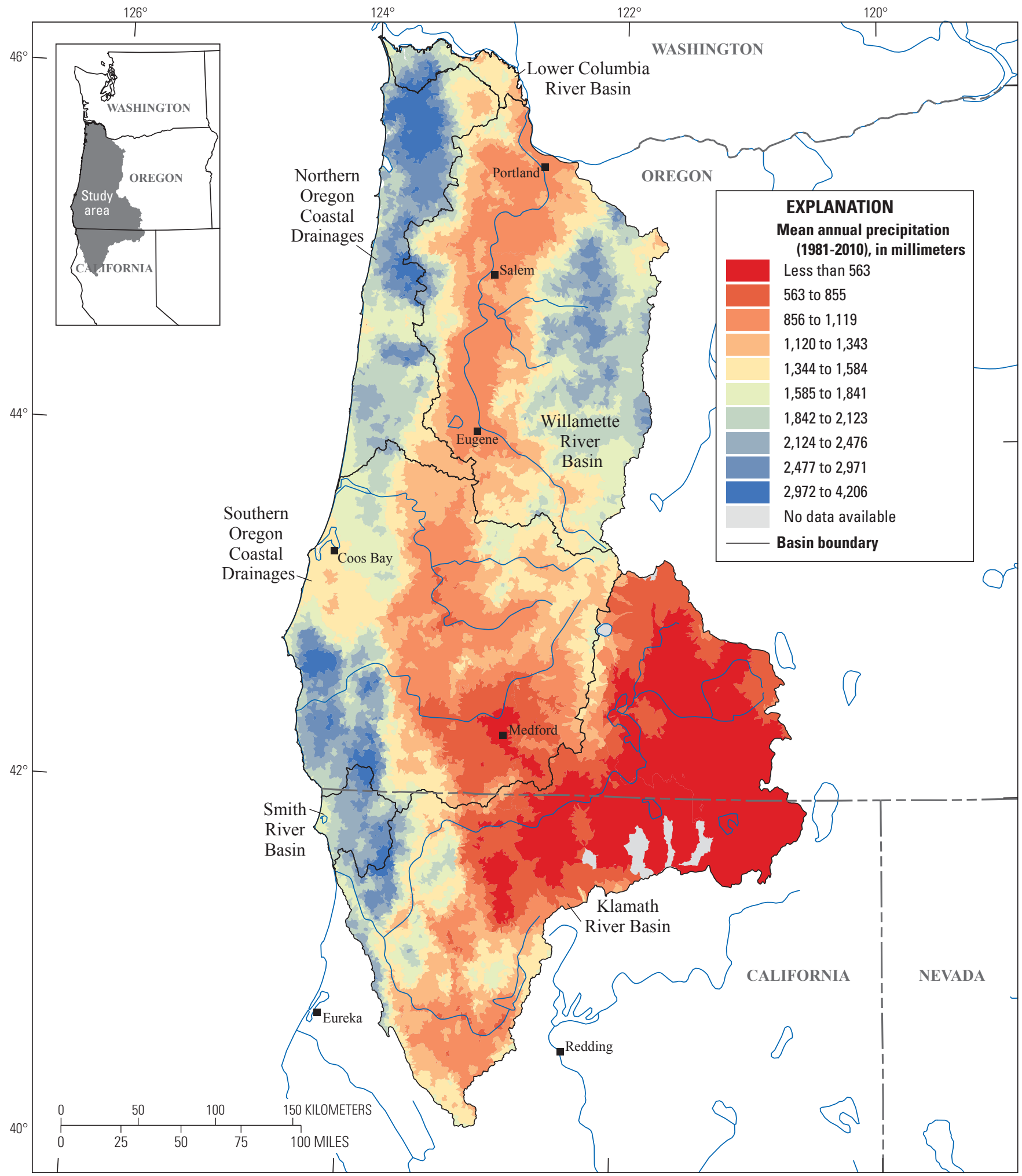

Base map modified from USGS and other digital data, various scales. Coordinate system: State Plane

Oregon North FIPS 3601. Horizontal datum: North American Datum of 1983 (HARN)

Figure 3. Mean annual precipitation within the modeling domain for the suspended sediment SPARROW models for western Oregon and northwestern California. 


\section{Methods}

\section{The SPARROW Model}

The SPARROW model is a hybrid statistical and mechanistic model for estimating the load of transported constituents (such as suspended sediment) through a stream network under long-term, steady state conditions (Schwarz and others, 2006; Preston and others, 2009). The model uses a non-linear least squares regression to empirically relate catchment and water body attributes (the explanatory or independent variables) to measured stream loads (the dependent variable) within a spatially explicit surface-water drainage network. Beginning in the headwater reaches, SPARROW performs the calibration by using initial model coefficient values to estimate the suspended-sediment load generated within the incremental catchment for each stream reach and the loss of sediment in free-flowing streams and impoundments (ponds, lakes, and artificial reservoirs). Each reach in the SPARROW model starts at a point of channel initiation or a tributary junction; the incremental catchment for each reach represents the area that drains directly to that reach. The incremental loads are accumulated moving downstream through the surface-water drainage network until a calibration station is reached, at which point the accumulated load is adjusted to match the measured load at the calibration station. The load accumulation process continues downstream after each calibration station adjustment and stops when a terminal reach (such as an estuary or internal drainage) is detected. The model then adjusts the initial coefficients based on the differences between the estimated and measured loads at the model calibration stations, re-estimates the accumulated suspended-sediment loads using the revised coefficients, and repeats the entire calibration process numerous times until the differences between the estimated and measured loads are minimized. Suspended-sediment loss in free-flowing streams is estimated in SPARROW using a first-order decay process, which is a function of the time of travel for each reach, whereas loss in impoundments is estimated using an apparent settling velocity expressed in units of length per time. A calibrated SPARROW model can simulate water-quality attributes (and their uncertainties) throughout a surface-water network, including areas where no water-quality data are available.

\section{Model Input Datasets}

A SPARROW model requires three datasets: (1) a dataset representing the surface-water drainage network within the modeling domain, (2) a set of calibration data, and (3) catchment attribute data. Except for revisions to the hydraulic properties of the impoundments, the input data used in the updated model were the same input data used in the original SPARROW model.

\section{Surface-Water Drainage Network}

The National Hydrography Dataset Version 2 (NHD Plus Version 2; Horizon Systems, 2013) defined the surface-water drainage network in the models developed for this study. This vector dataset comprehensively depicts and categorizes surface-water features such as lakes, ponds, streams, and rivers (Simley and Carswell, 2009) and closely corresponds to features on 1:100,000 scale U.S. Geological Survey (USGS) topographic maps. The hydrography data within the modeling domain consisted of 35,393 stream reaches and their associated incremental catchments. The streams ranged from small, intermittent streams to large rivers such as the Willamette River, with a mean annual streamflow of $940 \mathrm{~m}^{3} / \mathrm{s}$ near its confluence with the Columbia River (U.S. Geological Survey, 2015). Most reaches defined in the NHD Plus Version 2 represent streams, impoundments, or coastlines, but some represent closed basins, which do not have a surface water connection to other reaches and were not included in the model because sediment generated in such basins does not enter the broader hydrologic network. The hydraulic properties used to estimate permanent sediment loss in impoundments due to settling that were included in the original SPARROW model were replaced with estimates obtained from a revised national dataset (Gregory Schwarz, U.S. Geological Survey, written commun., May 9, 2017).

Irrigation canals divert water from streams and reservoirs in some area of western Oregon and northwestern California. The model accounted for these diversions by using an estimate of the fraction of streamflow and suspended-sediment load that was removed from the stream network. These estimates of local irrigation diversions were based on measurements of long-term average diversion records and streamflow. Although the model did not explicitly account for suspended-sediment load removed by irrigation diversions and eventually returned in irrigation return flow that could also include additional sediment from local runoff, the surface-water drainage network used in the models did include many of these agricultural returns. 


\section{Calibration Load Data}

The same 68 suspended sediment calibration stations that were used in the original SPARROW model also were used in the updated model (see appendix 1). These stations were operated by the USGS, two state agencies, two local agencies, and one university research center. The data for the USGS calibration stations were obtained from the National Water Information System (U.S. Geological Survey, 2015). The data for the California Department of Water Resources stations were obtained from that agency's on-line Data Library (California Department of Water Resources, 2015), the data for the Oregon Department of Environmental Quality stations were obtained from that agency's Laboratory Analytical Storage and Retrieval (LASAR) Web Application (Oregon Department of Environmental Quality, 2015b) and the data for the Andrews Experimental Forest station were obtained from that organization's on-line data catalogue (Andrews Experimental Forest, 2015). The data for the Clean Water Services station and the city of Portland stations were obtained directly from those agencies (Steven Anderson, Clean Water Services, written commun., June 2014: Peter Abrams, Portland Bureau of Environmental Services, written commun., May 2014).

Selected calibration stations were near a streamgage (the drainage area for each calibration station was within 50 percent of the drainage area for the corresponding streamgage and there were no major hydrologic modifications between the two locations) and had at least 23 suspended-sediment measurements between water years ${ }^{1} 1983$ and 2012, with at least three samples collected during each season of measurement record. All but one of the stations had suspended-sediment measurements that spanned at least 5 years (one record from a calibration station was a few days short of 5 years). Mean annual suspended-sediment loads for each of these calibration stations were estimated using the USGS Fluxmaster program, which combines long-term streamflow and sediment data to produce a detrended value for a specified base year, normalized to average hydrologic conditions (Schwarz and others, 2006). The loads used to calibrate the models for this study were detrended to water year 2012, and therefore accounted for differences in measurement record lengths and timing, long-term trends, as well as peculiarities of hydrologic conditions during any specific year within the 1983-2012 period (Preston and others, 2009).

\footnotetext{
${ }^{1}$ The 12-month period from October 1, for any given year, through September 30 of the following year. The water year is designated by the calendar year in which it ends.
}

Both the original and the updated SPARROW models relied on measurements of suspended sediment for the calibration dataset. These measurements, however, were based on two different methods - the standard suspended sediment (SSC) method used at 11 calibration stations and the total suspended solids (TSS) method used at 57 calibration stations. Standard suspended-sediment concentration is the mass of all the sediment within a known volume of a water-sediment mixture collected directly from a water body (Guy, 1969). In contrast, TSS is the mass of suspended material within a subsample of a water-sediment mixture collected from a water body. Such subsampling introduces negative bias and more variability, especially when the percentage of sandsize sediment is high (because of sediment settling before subsampling; Gray and others, 2000). Values determined by both methods generally are not used interchangeably (Gray and others, 2000). The original SPARROW model included the 57 calibration stations where TSS was measured and the 11 calibration stations where standard suspended sediment was measured because the latter were not in themselves sufficient for satisfactory model calibration. Although the updated SPARROW models used the same calibration stations as the original model, the updated models also included a newly available technique that accounted for the bias associated with the TSS measurements (Gregory Schwarz, U.S. Geological Survey, written commun., April 7, 2017). The new version of the SPARROW model evaluates an independent variable that takes a value of one (indicating a TSS load) or a value of zero. During model calibration, SPARROW estimates a coefficient for this independent variable. Because this coefficient applies only to reaches associated with a TSS calibration load it can be interpreted as a scaling factor for converting TSS calibration loads to SSC calibration loads.

\section{Catchment Attribute Data}

Catchment attributes served as explanatory variables for estimating the measured suspended-sediment loads used to calibrate the models. Potential explanatory variables in SPARROW model applications span a wide range of landscape and network attributes, depending on available information and factors considered important for simulating constituent loads. To enable broad and consistent SPARROW modeling efforts, many landscape properties have been compiled by the USGS National Water-Quality Assessment Program on a national basis for the incremental catchments in the NHD Plus Version 2 (Preston and others, 2009; Michael Wieczorek, U.S. Geological Survey, written commun., June 11, 2011, and March 10, 2015). 
Table 1. Potential explanatory variables evaluated in the updated suspended sediment SPARROW models for western Oregon and northwestern California.

[NLCD, National Land Cover Database]

\begin{tabular}{|c|c|c|}
\hline \multicolumn{2}{|c|}{ Landscape attributes } & \multirow{2}{*}{$\begin{array}{c}\text { Network attributes } \\
\begin{array}{c}\text { Potential aquatic } \\
\text { loss factors }\end{array}\end{array}$} \\
\hline $\begin{array}{l}\text { Potential sediment } \\
\text { sources }\end{array}$ & $\begin{array}{l}\text { Potential land-to-water } \\
\text { delivery factors }\end{array}$ & \\
\hline Stream channel (reach length) & Mean annual precipitation & Sediment removal in free-flowing streams \\
\hline Area of Coast Range sedimentary lithologic group & Mean slope & Sediment removal in impoundments \\
\hline Area of Coast Range volcanic lithologic group & Wildfire disturbance & \\
\hline Area of Klamath Terrane & Percentage of forest land & \\
\hline Area of Quaternary deposits & Percentage of agricultural land & \\
\hline Area of Western Cascades lithologic group & Percentage of forest cover loss & \\
\hline Area of High Cascades lithologic group & Mean canopy cover & \\
\hline Area of NLCD forest land & Soil erodibility factor & \\
\hline \multicolumn{3}{|l|}{ Area of NLCD scrub and grass land } \\
\hline \multicolumn{3}{|l|}{ Area of NLCD agricultural land } \\
\hline Area of NLCD developed land & & \\
\hline
\end{tabular}

The same potential explanatory variables that were evaluated in the calibration of the original SPARROW model were evaluated in the updated models (table 1). These data represented land cover, geology, climate, soil properties, and hydrology. Most of these landscape properties were compiled by the National Water-Quality Assessment Program, but two datasets were compiled specifically for the modeling domain of this SPARROW application: (1) six generalized lithologic provinces defined by O'Connor and others (2014); and (2) areas experiencing diminished forest cover between 2000 and 2014 obtained from the Department of Geographical Sciences at the University of Maryland (Hansen and others, 2013). The lithology and forest-cover loss data were related to the hydrography in a manner similar to the national landscape attribute data.

\section{Model Calibration}

The catchment attributes evaluated in the model calibration were selected based on assumptions about the factors that control landscape sediment yields (table 1). Six lithologic provinces (table 2) and four land-cover classifications (table 3 ) were evaluated as sources of landscape sediment. Sediment delivery to streams was evaluated by considering landscape characteristics such as precipitation, slope, land cover and disturbance, and soil properties. Hydrologic network attributes that might increase instream suspended-sediment load (by bank erosion or bed-material comminution along a stream reach) also were considered as well as attributes that could decrease suspended-sediment load, such as loss in free-flowing streams (through channel or floodplain deposition) and impoundments (through sediment settling).
Table 2. Description of lithologic provinces evaluated as sources in the updated suspended sediment SPARROW models for western Oregon and northwestern California.

[Locations of lithologic provinces are shown in figure 2]

\begin{tabular}{|c|c|}
\hline Lithologic province & Description \\
\hline Coast Range sedimentary & $\begin{array}{l}\text { Paleocene to Oligocene marine } \\
\text { sandstone and siltstone. }\end{array}$ \\
\hline Coast Range volcanics & $\begin{array}{l}\text { Paleocene to Eocene basalt and diabase } \\
\text { in the Coast Range and Miocene } \\
\text { Columbia River Basalt Group in the } \\
\text { northern part of the model area. }\end{array}$ \\
\hline Klamath & $\begin{array}{l}\text { Tectonically accreted and uplifted } \\
\text { Paleozoic and Mesozoic rocks } \\
\text { in southwestern Oregon and } \\
\text { northwestern California. Most are } \\
\text { metamorphosed to some degree. }\end{array}$ \\
\hline Quaternary & $\begin{array}{l}\text { Unconsolidated Quaternary sediment } \\
\text { within basins, valley bottoms, } \\
\text { glaciated areas, and coastal plains. }\end{array}$ \\
\hline Western Cascades & $\begin{array}{l}\text { Eocene to Pliocene volcanic rocks } \\
\text { associated with early phases of } \\
\text { Cascade Range volcanism. }\end{array}$ \\
\hline High Cascades & $\begin{array}{l}\text { Quaternary basalts and andesites of the } \\
\text { modern Cascade Range volcanic arc. }\end{array}$ \\
\hline
\end{tabular}


Table 3. Description of generalized land-cover classes evaluated as sources in the updated suspended sediment SPARROW models for western Oregon and northwestern California.

\begin{tabular}{ll}
\hline $\begin{array}{c}\text { Generalized land- } \\
\text { cover class }\end{array}$ & \multicolumn{1}{c}{$\begin{array}{c}\text { Individual 2011 National Land Cover } \\
\text { Database land-cover classes }\end{array}$} \\
\hline Forest land & $\begin{array}{l}\text { Deciduous forest } \\
\text { Evergreen forest } \\
\text { Mixed forest }\end{array}$ \\
& $\begin{array}{l}\text { Shrub/scrub } \\
\text { Grassland/herbaceous }\end{array}$ \\
Scrub and grass land & Pasture/hay \\
Agricultural land & Cultivated crops \\
& Developed, open space \\
Developed land & Developed, low intensity \\
& Developed, medium intensity \\
& Developed high intensity \\
\hline
\end{tabular}

The model calibration results were evaluated using standard statistical diagnostics. A significance level of 0.10 (based on a one-sided t-test) was applied to explanatory variables that could relate only to suspended-sediment loads in a positive manner. These variables included the lithology and land-cover classifications (because only positive sediment loads were possible) and the sediment loss in free-flowing streams and impoundments. Significance was judged with a two-sided significance level of 0.05 for variables where the relation to suspended-sediment loads could be either positive or negative. Final model selection was based on the significance of the model coefficients, the root mean squared error (RMSE), the yield coefficient of determination $\left(\mathrm{R}^{2}\right)$, and the spatial patterns in the residuals. The yield $\mathrm{R}^{2}$ is the $\mathrm{R}^{2}$ value for the natural logarithm of yield and is a better measure of goodness of fit than the $\mathrm{R}^{2}$ of the calibration loads because it normalizes for the effect of contributing area, which can explain much of the variation in stream load. The RMSE, when multiplied by 100 , is approximately equal to one standard deviation percent error associated with the estimation for any single reach and was calculated using two different methods. The first method was the conditioned RMSE that reflected the difference between the measured calibration loads and the estimated accumulated loads that were reset to the measured loads during model calibration, and this statistic is useful for evaluating the model calibration results. The second method was the unconditioned RMSE that reflected the difference between the measured calibration loads and the estimated accumulated loads without any adjustments; this statistic is useful for evaluating the accuracy of the model simulations. The spatial patterns in model fit were evaluated by calculating and mapping the studentized residuals, which are equal to the model residual divided by an estimate of its standard deviation.

The SPARROW model uses a nonlinear least squares (NLLS) regression to estimate model coefficients and provides a way to assess uncertainty in these estimated coefficients. Because of the nonlinear way the estimated coefficients enter the model, this uncertainty is evaluated using a bootstrap resampling method (Schwarz and others, 2006) entailing repeated estimation of the model (200 times in this case of this application of the model) to obtain a range of values for each coefficient. A mean value (the nonparametric bootstrap estimate) is then estimated based on the results from this evaluation. The overall stability of the models was evaluated by comparing the nonlinear regression estimates of the model coefficients to the nonparametric bootstrap estimates. The bootstrap resampling method also was used to determine the 90 percent confidence intervals for the estimated coefficients in the models.

\section{Calibration Results and Predictions}

The calibration results indicated that two different SPARROW models were possible: (1) a model in which sediment sources were represented by local lithology (table 4); and (2) a model in which sediment sources were represented by generalized land-cover classes (table 5). Five of the six lithologic provinces were significantly correlated to suspended-sediment loads, but the High Cascades lithologic province was not - indicating that areas of this geologic province contribute negligible amounts to suspendedsediment load. Quaternary deposits were, on average, the largest incremental contributor to suspended sediment delivered to streams in the lithology-based model, whereas the Coast Range volcanic lithologic province was the smallest contributor (table 6). All four of the generalized land-cover classes were significantly correlated to suspended-sediment loads and forest land was, on average, the largest incremental contributor to suspended sediment delivered to streams and developed land was the smallest contributor (table 6). Both models also included significant explanatory variables that represented mean annual precipitation, mean catchment slope, wildfire disturbance, sediment loss in impoundments, and differences between measured total suspended solids and suspended-sediment loads. The positive model coefficients for precipitation, slope, and wildfire disturbance showed that these attributes were positively correlated with suspended-sediment loads. None of the other potential explanatory variables related to delivery to streams and aquatic loss were statistically significant in either model. 
Table 4. Calibration results from the updated lithology-based suspended sediment SPARROW model for western Oregon and northwestern California.

[Abbreviations: cm, centimeter; $\left(\mathrm{kg} / \mathrm{km}^{2}\right) / \mathrm{yr}$, kilogram per square kilometer per year; $\mathrm{km}^{2}$, square kilometer; $\mathrm{m}$, meter; $\mathrm{m} / \mathrm{d}$, meter per day; NLSS, non-linear least squares; RMSE, root mean square error; <, less than; -, not applicable]

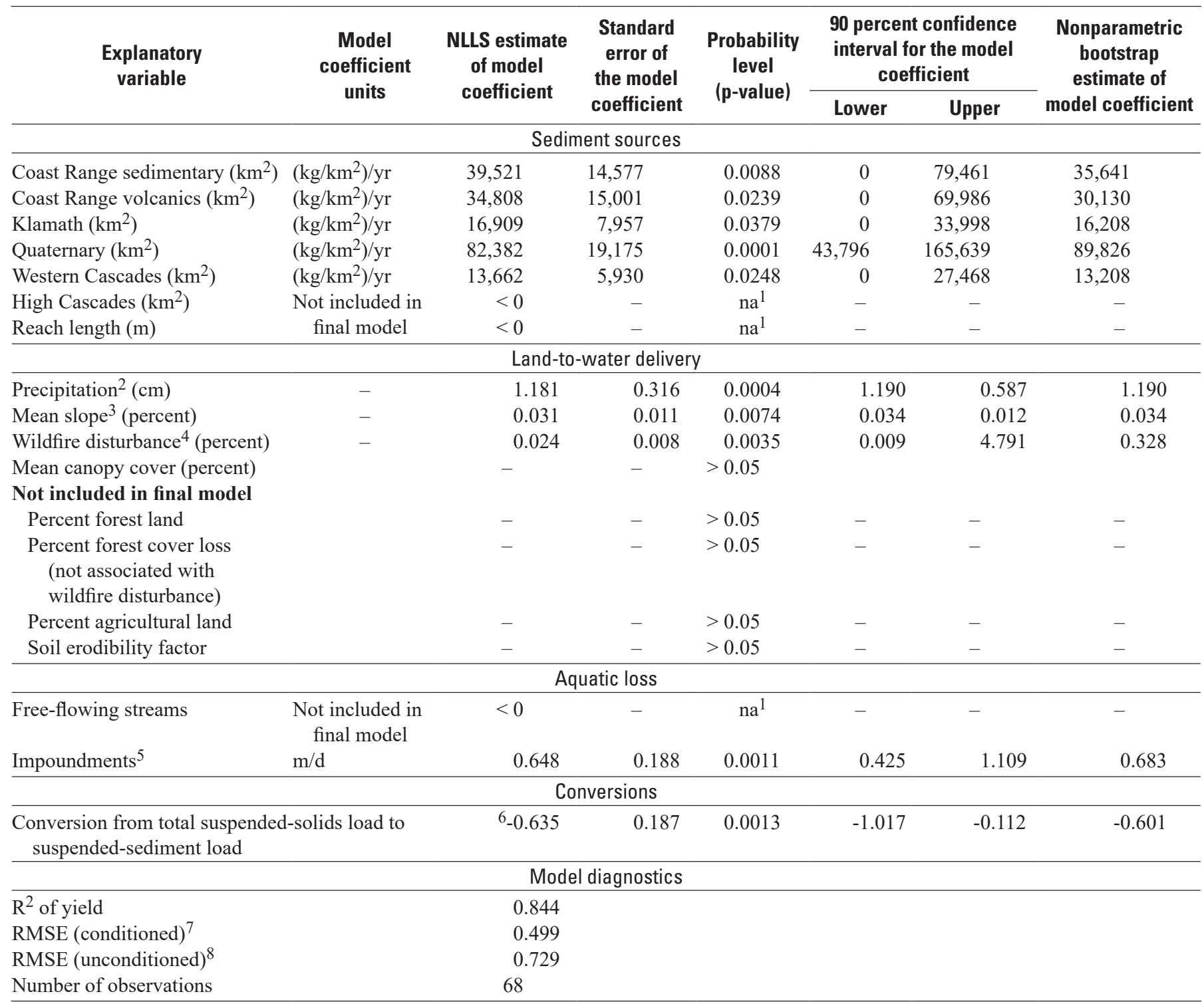

${ }^{1}$ Statistical significance was not applicable because of the negative estimate for the coefficient.

${ }^{2}$ Natural log of mean annual precipitation (1981-2010).

${ }^{3}$ Mean slope of incremental catchment.

${ }^{4}$ Cumulative area disturbed by wildfire between 2003 and 2012.

${ }^{5}$ Sediment loss in natural impoundments and reservoirs expressed as a settling velocity.

${ }^{6}$ The value of -0.635 is equivalent to a factor of 1.89 to convert total suspended-solids load to suspended-sediment load

${ }^{7}$ Reflects the difference between the measured calibration loads and the predicted accumulated loads that were reset to the measured loads at calibration stations.

${ }^{8}$ Reflects the difference between the measured calibration loads and the predicted accumulated loads that were no reset to the measured loads at calibration stations. 


\section{Updates to the Suspended Sediment SPARROW Model Developed for Western Oregon and Northwestern California}

Table 5. Calibration results from the updated land-cover based suspended sediment SPARROW model for western Oregon and northwestern California.

[Land-cover classes are from National Land Cover Database (Homer and others, 2012). Abbreviations: cm, centimeter; $\left(\mathrm{kg} / \mathrm{km}^{2}\right) / \mathrm{yr}$, $\mathrm{kilogram} \mathrm{per} \mathrm{square}$ kilometer per year; $\mathrm{km}^{2}$, square kilometer; $\mathrm{m}$, meter; $\mathrm{m} / \mathrm{d}$, meter per day; NLSS, non-linear least squares; RMSE, root mean square error; >, greater than; <, less than; -, not applicable]

\begin{tabular}{|c|c|c|c|c|c|c|c|}
\hline \multirow[t]{2}{*}{$\begin{array}{c}\text { Explanatory } \\
\text { variable }\end{array}$} & \multirow{2}{*}{$\begin{array}{l}\text { Model } \\
\text { coefficient } \\
\text { units }\end{array}$} & \multirow{2}{*}{$\begin{array}{l}\text { NLLS estimate } \\
\text { of model } \\
\text { coefficient }\end{array}$} & \multirow{2}{*}{$\begin{array}{l}\text { Standard } \\
\text { error of } \\
\text { the model } \\
\text { coefficient }\end{array}$} & \multirow{2}{*}{$\begin{array}{c}\text { Probability } \\
\text { level } \\
\text { (p-value) }\end{array}$} & \multicolumn{2}{|c|}{$\begin{array}{c}90 \text { percent confidence } \\
\text { interval for the model } \\
\text { coefficient }\end{array}$} & \multirow{2}{*}{$\begin{array}{l}\text { Nonparametric } \\
\text { bootstrap } \\
\text { estimate of } \\
\text { model coefficient }\end{array}$} \\
\hline & & & & & Lower & Upper & \\
\hline \multicolumn{8}{|c|}{ Sediment sources } \\
\hline \multicolumn{8}{|l|}{ Land-cover class } \\
\hline Forest land $\left(\mathrm{km}^{2}\right)$ & $\left(\mathrm{kg} / \mathrm{km}^{2}\right) / \mathrm{yr}$ & 20,684 & 9,232 & 0.0288 & 2,822 & 41,044 & 25,603 \\
\hline Developed land $\left(\mathrm{km}^{2}\right)$ & $\left(\mathrm{kg} / \mathrm{km}^{2}\right) / \mathrm{yr}$ & 38,692 & 16,015 & 0.0188 & 9,852 & 74,407 & 31,778 \\
\hline Reach length (m) & $\begin{array}{l}\text { Not included in } \\
\text { final model }\end{array}$ & $<0$ & - & $\mathrm{na}^{1}$ & - & - & - \\
\hline \multicolumn{8}{|c|}{ Land-to-water delivery } \\
\hline Precipitation $^{2}(\mathrm{~cm})$ & - & 1.651 & 0.238 & $<0.0001$ & 1.098 & 2.189 & 1.609 \\
\hline \multicolumn{8}{|l|}{ Not included in final model } \\
\hline $\begin{array}{l}\text { Percentage of forest cover loss } \\
\text { (not associated with wildfire } \\
\text { disturbance) }\end{array}$ & & - & - & $>0.05$ & - & - & - \\
\hline Soil erodibility factor & & - & - & $>0.05$ & - & - & - \\
\hline \multicolumn{8}{|c|}{ Aquatic loss } \\
\hline Free-flowing streams & $\begin{array}{l}\text { Not included in } \\
\text { final model }\end{array}$ & $<0$ & - & $\mathrm{na}^{1}$ & - & - & - \\
\hline Impoundments ${ }^{5}$ & $\mathrm{~m} / \mathrm{d}$ & 0.892 & 0.328 & 0.0085 & 0.441 & 1.189 & 0.825 \\
\hline \multicolumn{8}{|c|}{ Conversions } \\
\hline
\end{tabular}

${ }^{1}$ Statistical significance was not applicable because of the negative estimate for the coefficient.

${ }^{2}$ Natural log of mean annual precipitation (1981-2010).

${ }^{3}$ Mean slope of incremental catchment.

${ }^{4}$ Cumulative area disturbed by wildfire between 2003 and 2012.

${ }^{5}$ Sediment loss in natural impoundments and reservoirs expressed as a settling velocity.

${ }^{6}$ The value of -0.671 is equivalent to a factor of 1.89 to convert total suspended-solids load to suspended-sediment load.

${ }^{7}$ Reflects the difference between the measured calibration loads and the estimated accumulated loads that were reset to the measured loads at calibration stations.

${ }^{8}$ Reflects the difference between the measured calibration loads and the estimated accumulated loads that were no reset to the measured loads at calibration stations. 
The lithology- and land-cover based models explained about 84 and 82 percent of the variability in measured suspended-sediment yield, respectively (based on the yield $\mathrm{R}^{2}$ values in tables 4 and 5). The conditioned RMSE for the lithology-based model was 0.499 compared to an unconditioned RMSE of 0.729 , and the conditioned RMSE value for land-cover based model was 0.538 compared to an unconditioned RMSE of 0.774 . The large differences between the conditioned and unconditioned RMSE values means that both models were better at matching the calibration loads when the accumulated loads were reset at each upstream calibration station compared to when they were not reset. Because the predictions obtained from the models were based on accumulated loads that were not reset at the calibration stations, the unconditioned RMSE value for each model is a useful statistic for evaluating the overall accuracy of those predictions.
The NLLS regression coefficients for most of the model terms generally were close to the nonparametric bootstrap estimates (the exception was the wildfire disturbance term in both models) but the 90 percent confidence intervals for most coefficients were also large. For the lithology-based model there was an overall pattern of model under-prediction in all the major watersheds except for the northern Oregon coastal drainages, and for the land-cover based model there was an overall pattern of model under-prediction in all the major watersheds except for the Klamath River Basin (figs. 4 and 5, table 7). The suspended-sediment loads predicted by the lithology-based model ranged from about 0.4 to 5.2 times the measured loads at the 68 calibration stations, whereas the loads predicted by the land-cover based model ranged from about 0.5 to 6.5 times the measured loads. For both models, however, the average ratio was about 2 between measured values and model predictions results (appendix 1).

Table 6. Summary statistics for incremental loads simulated by the updated suspended sediment SPARROW models for western Oregon and northwestern California.

[Lithologic provinces are shown in figure 2. Land-cover classes are from National Land Cover Database (Homer and others, 2012). Mean source share: Percentage of the total amount of suspended-sediment load delivered to streams wate was contributed by each lithologic province or land-cover class. Share of modeling domain: Percentage of modeling domain that consists of each lithologic province or land-cover class]

\begin{tabular}{|c|c|c|c|c|c|}
\hline \multicolumn{3}{|c|}{ Lithology-based model } & \multicolumn{3}{|c|}{ Land-cover based model } \\
\hline $\begin{array}{l}\text { Lithologic } \\
\text { province }\end{array}$ & $\begin{array}{c}\text { Mean } \\
\text { source } \\
\text { share } \\
\text { (percent) }\end{array}$ & $\begin{array}{l}\text { Share of } \\
\text { modeling } \\
\text { domain } \\
\text { (percent) }\end{array}$ & $\begin{array}{l}\text { Land-cover } \\
\text { class }\end{array}$ & $\begin{array}{c}\text { Mean } \\
\text { source } \\
\text { share } \\
\text { (percent) }\end{array}$ & $\begin{array}{c}\text { Share of } \\
\text { modeling } \\
\text { domain } \\
\text { (percent) }\end{array}$ \\
\hline Coast Range sedimentary & 15 & 15 & Forest land & 45 & 59 \\
\hline Coast Range volcanic & 5.8 & 5.9 & Scrub and grass land & 36 & 24 \\
\hline Klamath & 29 & 27 & Agricultural land & 11 & 8.5 \\
\hline Quaternary & 32 & 17 & Developed land & 7.8 & 4.6 \\
\hline Western Cascades & 18 & 22 & & & \\
\hline
\end{tabular}

Table 7. Summary of calibration results for the original and updated suspended sediment SPARROW models for western Oregon and northwestern California.

[Locations of drainage basins are shown in figure 1. Median studentized residual: Values less than zero indicate general overprediction, whereas values greater than zero indicate general underprediction. Original lithology model: From Wise and O'Connor (2016)]

\begin{tabular}{lccccc}
\hline \multicolumn{1}{c}{ Drainage basin } & $\begin{array}{c}\text { Share of } \\
\text { modeling domain } \\
\text { (percent) }\end{array}$ & $\begin{array}{c}\text { Number of } \\
\text { calibration } \\
\text { stations }\end{array}$ & $\begin{array}{c}\text { Original lithology } \\
\text { model }\end{array}$ & $\begin{array}{c}\text { Revised lithology } \\
\text { model }\end{array}$ & $\begin{array}{c}\text { Updated land- } \\
\text { cover model }\end{array}$ \\
\hline Lower Columbia River Basin & 1.3 & 0 & na & na & na \\
Northern Oregon Coastal drainages & 10 & 8 & -0.663 & -0.659 & -0.187 \\
Southern Oregon Coastal drainages & 27 & 11 & 0.378 & 0.048 & -0.071 \\
Willamette River Basin & 25 & 43 & -0.039 & 0.091 & -0.026 \\
Smith River Basin & 1.8 & 0 & na & na & na \\
Klamath River Basin & 35 & 6 & -0.263 & 0.359 & 0.316 \\
\hline
\end{tabular}




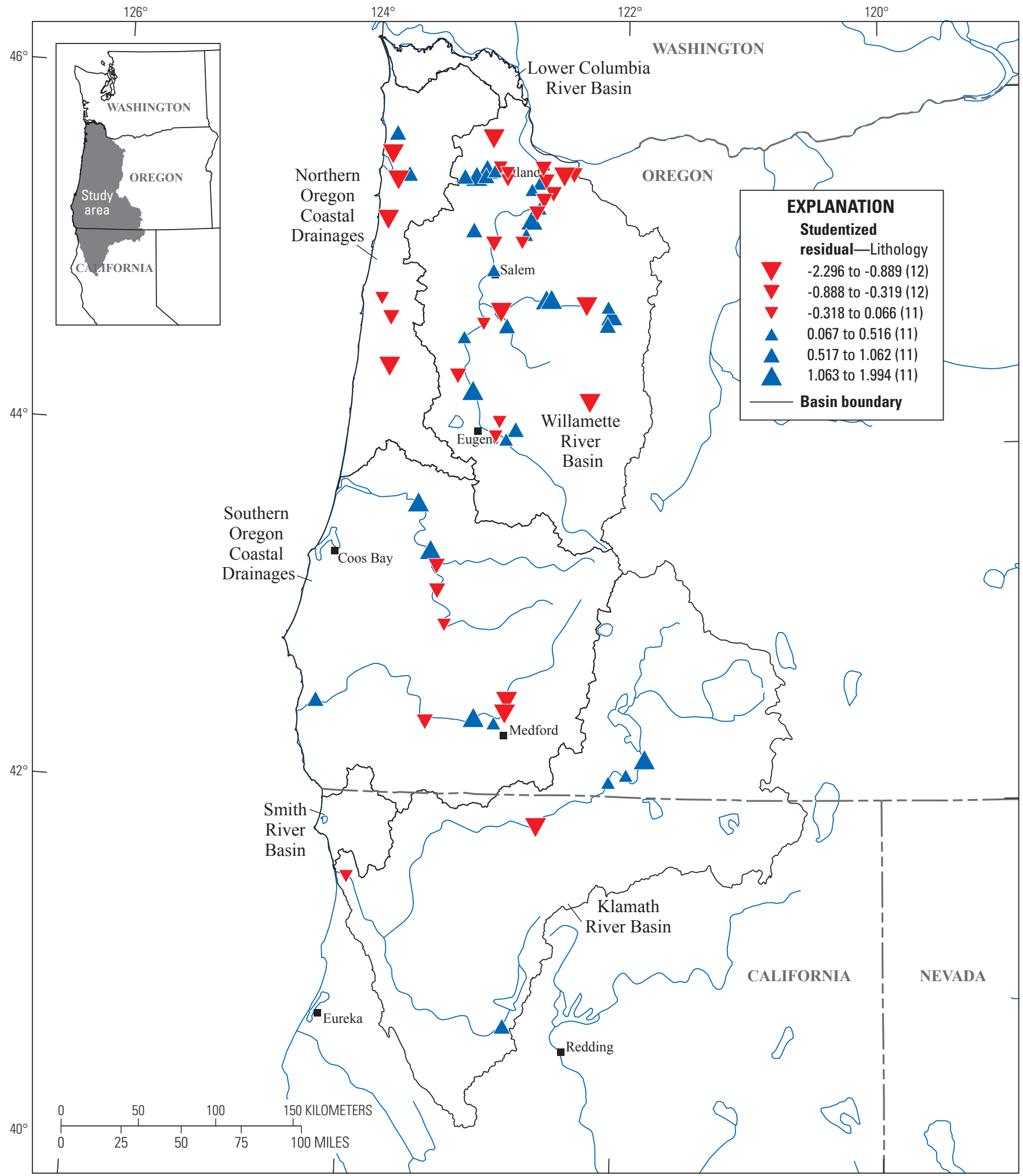

Base map modified from USGS and other digital data, various scales. Coordinate system: State Plane

Oregon North FIPS 3601. Horizontal datum: North American Datum of 1983 (HARN)

Figure 4. Studentized residuals for the updated lithology-based suspended sediment SPARROW model for western Oregon and northwestern California. 


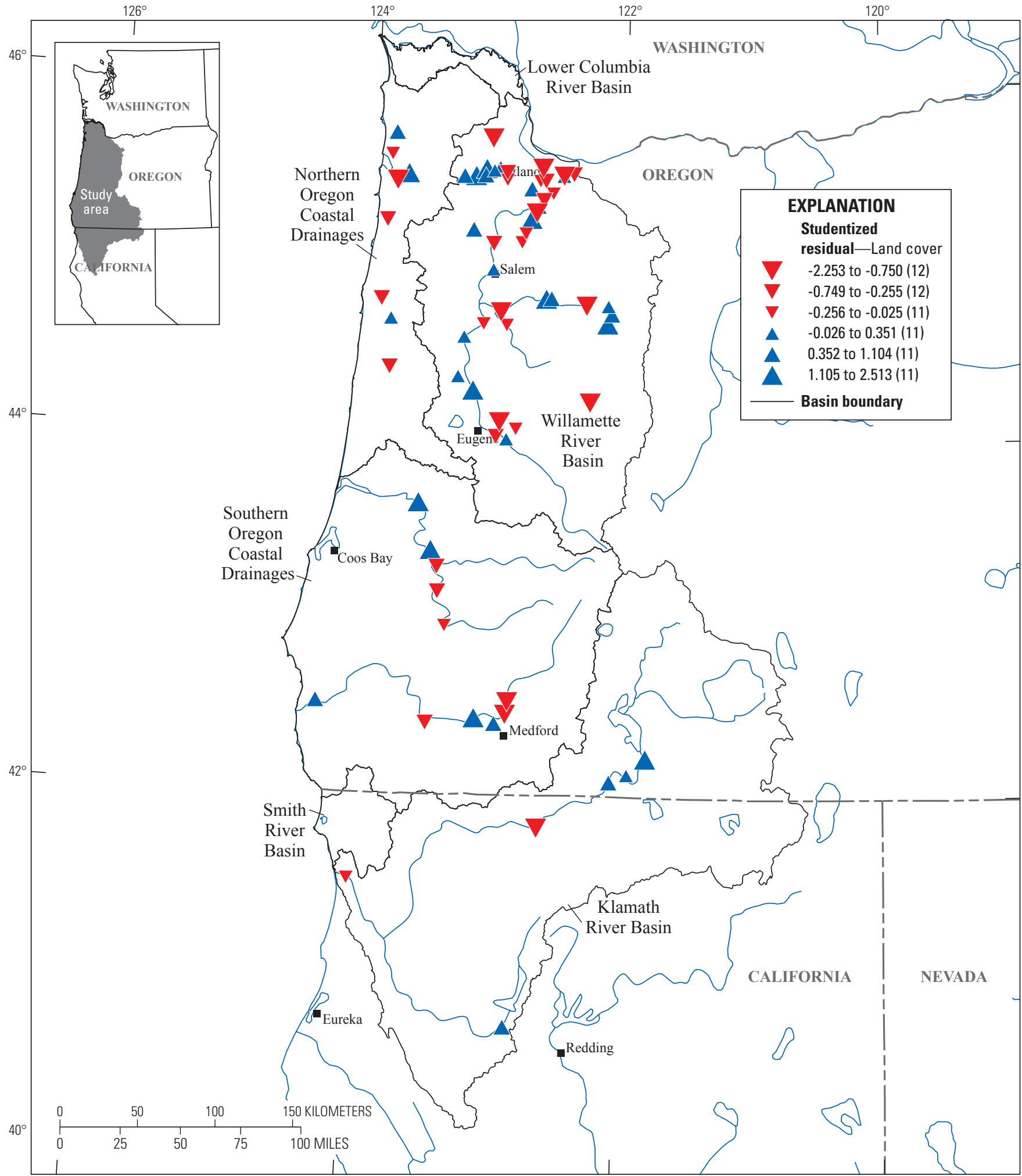

Base map modified from USGS and other digital data, various scales. Coordinate system: State Plane Oregon North FIPS 3601. Horizontal datum: North American Datum of 1983 (HARN)

Figure 5. Studentized residuals for the updated land-cover based suspended sediment SPARROW model for western Oregon and northwestern California. 
The final models enabled predictions of mean annual incremental yield and total load for each of the 35,393 stream reaches within the modeling domain along with estimates of the relative contribution to suspended-sediment load from different sources. Figure 6 shows the incremental suspendedsediment yields predicted by the lithology-based model — the results from the land-cover based model are not shown but the spatial patterns were similar. The highest median incremental suspended-sediment yield predicted by the lithology-based model was for the northern Oregon coastal drainages and the highest median incremental suspended-sediment yield predicted by the land-cover based model was for the Smith River Basin (table 8). The lowest median incremental suspended-sediment yield predicted by the lithology-based model was for the Klamath River Basin, but in some areas in that watershed near the Pacific Ocean, the incremental suspended-sediment yields were relatively high. The lowest median incremental suspended-sediment yield predicted by the land-cover based model was for the lower Columbia River drainages. The incremental yields predicted by the updated models were consistently greater than the values predicted by the original SPARROW model because of the inclusion of the TSS to SSC conversion term in both models, which resulted in substantially greater values for the source term coefficients. The prediction results for each of the 35,393 stream reaches from both the lithology-based and land-cover based models are available on-line (Wise, 2018).

The results from SPARROW can be used to estimate the relative contribution from individual sources and different areas to the suspended-sediment load in a specific stream reach. The reach of the Willamette River near its mouth in Portland, Oregon, provides a good example because the river drains a large basin consisting of various types of land cover and lithology (figs. 1 and 2). The lithology-based model showed that about one-half of the mean annual load in that reach came from unconsolidated Quaternary deposits and the other half came equally from Coast Range sedimentary and volcanic rocks and the Western Cascades (table 9). The landcover based model showed that 73 percent of the mean annual load in this reach (which was 15.6 percent greater than the load predicted by the lithology-based model) was due to runoff from forest, scrub, and grass land whereas 27 percent was due to runoff from agricultural and developed land (table 9). Both models also showed that the Upper Willamette River and Clackamas River watersheds contributed the most to the mean annual suspended-sediment load in this reach and that the Middle Willamette River, Middle Fork Willamette River, and Coast Fork Willamette River watersheds contributed the least (fig. 7 and table 10).

The results from SPARROW also can be used to evaluate the importance of different processes in the delivery of contaminants to downstream reaches. The lithology-based model was used to predict suspended-sediment delivery to the reach of the Willamette River near its mouth in Portland without including losses in upstream impoundments. Under this scenario the mean annual suspended-sediment load in this reach was 42 percent greater than the load predicted by the complete lithology-based model, which indicates that a substantial amount of the suspended-sediment load that would be delivered to the reach is retained in upstream impoundments. Running the model under this scenario also changed the estimates of the relative contribution from different watersheds (table 10). For example, the Middle Fork Willamette River watershed contributed a relatively small amount of the suspended-sediment load delivered to this reach when upstream impoundments were included in the model. When losses in upstream impoundments were not included in the model, however, this watershed contributed the second most of any of the watersheds - a result consistent with the Middle Fork Willamette River watershed having the highest percentage of area consisting of impounded waters.

Table 8. Median incremental yields and flow-weighted concentrations predicted by the original and updated suspended sediment SPARROW models for western Oregon and northwestern California.

[Locations of drainage basins are shown in figure 1. Values are in kilograms per hectare per year. Median incremental yield: Incremental yield is equal to the incremental suspended-sediment load divided by the incremental catchment area, where the incremental load is the load. Original lithology model: From Wise and O'Connor (2016)]

\begin{tabular}{lccc}
\hline \multirow{2}{*}{ Drainage basin } & \multicolumn{3}{c}{ Median incremental yield } \\
\cline { 2 - 4 } & $\begin{array}{c}\text { Original lithology } \\
\text { model }\end{array}$ & $\begin{array}{c}\text { Revised lithology } \\
\text { model }\end{array}$ & $\begin{array}{c}\text { Updated land- } \\
\text { cover model }\end{array}$ \\
\hline Lower Columbia River Basin & na & 419 & 220 \\
Northern Oregon Coastal drainages & 477 & 825 & 596 \\
Southern Oregon Coastal drainages & 129 & 323 & 311 \\
Willamette River Basin & 222 & 303 & 328 \\
Smith River Basin & 249 & 585 & 806 \\
Klamath River Basin & 57 & 193 & 238 \\
\hline
\end{tabular}




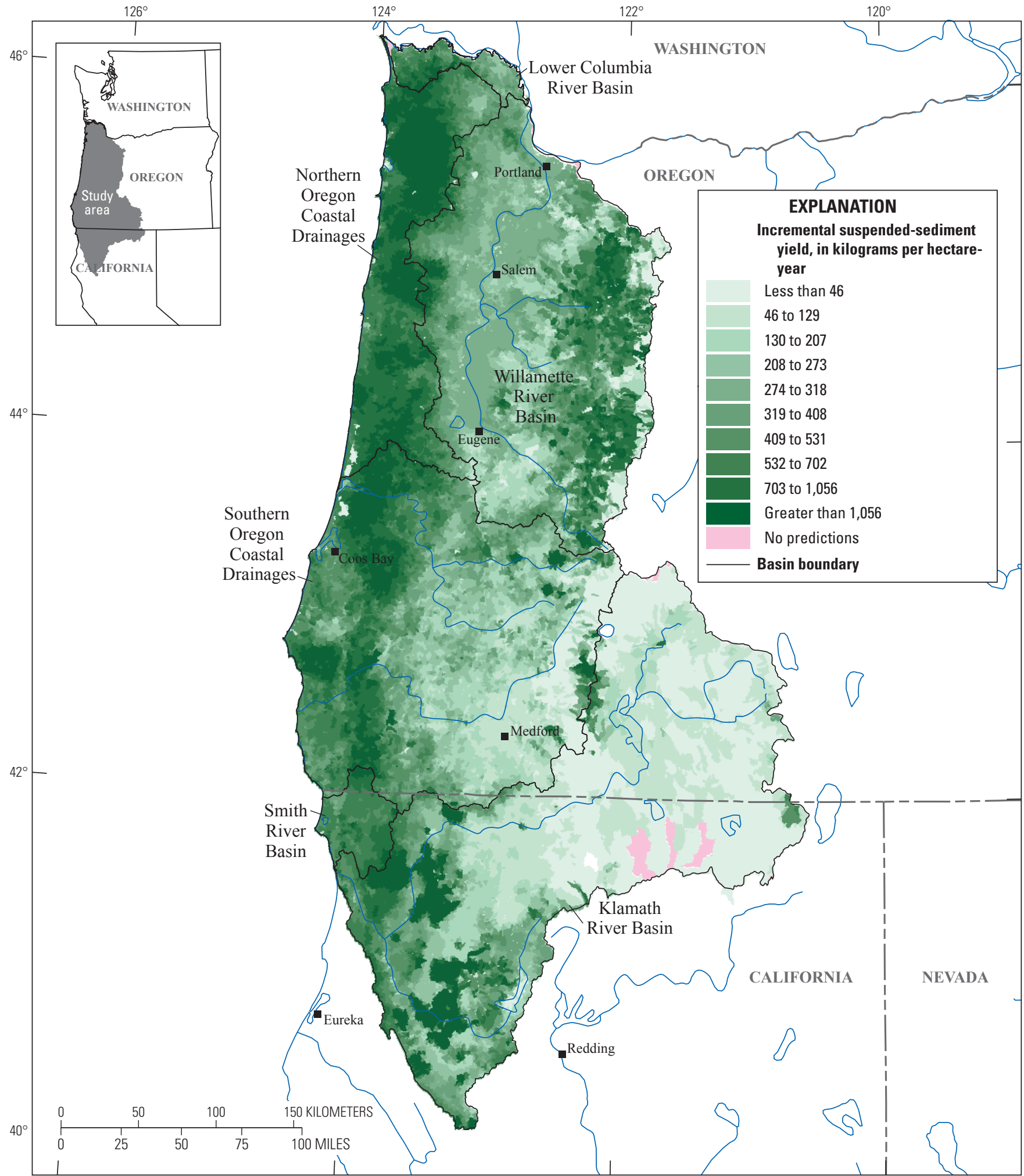

Base map modified from USGS and other digital data, various scales. Coordinate system: State Plane Oregon North FIPS 3601. Horizontal datum: North American Datum of 1983 (HARN)

Figure 6. Incremental suspended-sediment yields predicted by the updated lithology-based suspended sediment SPARROW model for western Oregon and northwestern California. 
Table 9. Suspended-sediment conditions in the lower Willamette River, Oregon, as predicted by the updated suspended sediment SPARROW models for western Oregon and northwestern California.

[Lithologic provinces are shown in figure 2. Land-cover classes are from National Land Cover Database (Homer and others, 2012). Source share: The percentage of the total amount of suspended-sediment load delivered to streams that was contributed by each lithologic province or land-cover class. Abbreviations: (kg/ha)/yr, kilogram per hectare per year; t/yr, metric ton per year; NLCD, National Land Cover Database; USGS, U.S. Geological Survey]

\begin{tabular}{|c|c|c|c|c|}
\hline \multicolumn{2}{|l|}{ Lithology-based model } & \multicolumn{2}{|l|}{ Land-cover based model } & \\
\hline Lithologic province & $\begin{array}{c}\text { Source share } \\
\text { (percent) }\end{array}$ & Land-cover class & $\begin{array}{c}\text { Source share } \\
\text { (percent) }\end{array}$ & \\
\hline Coast Range sedimentary & 14 & Forest land & 37 & \\
\hline Coast Range volcanics & 12 & Scrub and grass land ${ }^{1}$ & 36 & \\
\hline Klamath & 0 & Agricultural land & 20 & \\
\hline Quaternary & 52 & Developed land & 7.6 & \\
\hline \multirow[t]{2}{*}{ Western Cascades } & 22 & & & \\
\hline & & & & $\begin{array}{c}\text { Measured } \\
\text { values }^{2}\end{array}$ \\
\hline Total suspended-sediment load (t/yr) & 761,918 & Total suspended-sediment load (t/yr) & 880,934 & 649,528 \\
\hline Total suspended-sediment yield ([kg/ha $] / \mathrm{yr})$ & 263 & Total suspended-sediment yield $([\mathrm{kg} / \mathrm{ha}] / \mathrm{yr})$ & 305 & 225 \\
\hline
\end{tabular}

${ }^{1}$ For the Willamette River Basin this category consisted of 75 percent scrub land and 25 percent grass land.

${ }^{2}$ Measured suspended-sediment load and yield at USGS streamgage 14211720. The data collected at this streamgage include water-quality as well as streamflow data.

Table 10. Contribution from selected watersheds to the estimated suspended-sediment load delivered to the Willamette River near Portland, Oregon, as predicted by the updated suspended sediment SPARROW models for western Oregon and northwestern California.

[Locations of watersheds are shown in figure 7]

\begin{tabular}{lccc}
\hline \multirow{2}{*}{\begin{tabular}{l} 
Watershed \\
\cline { 2 - 3 }
\end{tabular}} & \multicolumn{2}{c}{$\begin{array}{c}\text { Contribution to suspended-sediment load delivered to the } \\
\text { mouth of the Wilamette River (percent) }\end{array}$} \\
\cline { 2 - 4 } & $\begin{array}{c}\text { Lithology- } \\
\text { based model }\end{array}$ & $\begin{array}{c}\text { Lithology-based model with } \\
\text { no impoundment loss }\end{array}$ & $\begin{array}{c}\text { Land-cover } \\
\text { based model }\end{array}$ \\
\hline Upper Willamette River & 21.6 & 15.9 & 19.9 \\
Clackamas River & 15.2 & 11.9 & 12.2 \\
Yamhill River & 11.2 & 8.6 & 9.2 \\
Molalla and Pudding Rivers & 9.2 & 6.6 & 11.8 \\
North Santiam River & 7.8 & 12.4 & 7.8 \\
South Santiam River & 7.4 & 8.9 & 11.1 \\
Mckenzie River & 7.2 & 6.6 & 9.8 \\
Tualatin River & 7.7 & 5.9 & 5.8 \\
Middle Willamette River & 5.9 & 4.9 & 5.3 \\
Middle Fork Willamette River & 3.1 & 13.7 & 3.0 \\
Coast Fork Willamette River & 2.3 & 3.6 & 2.7 \\
\hline
\end{tabular}




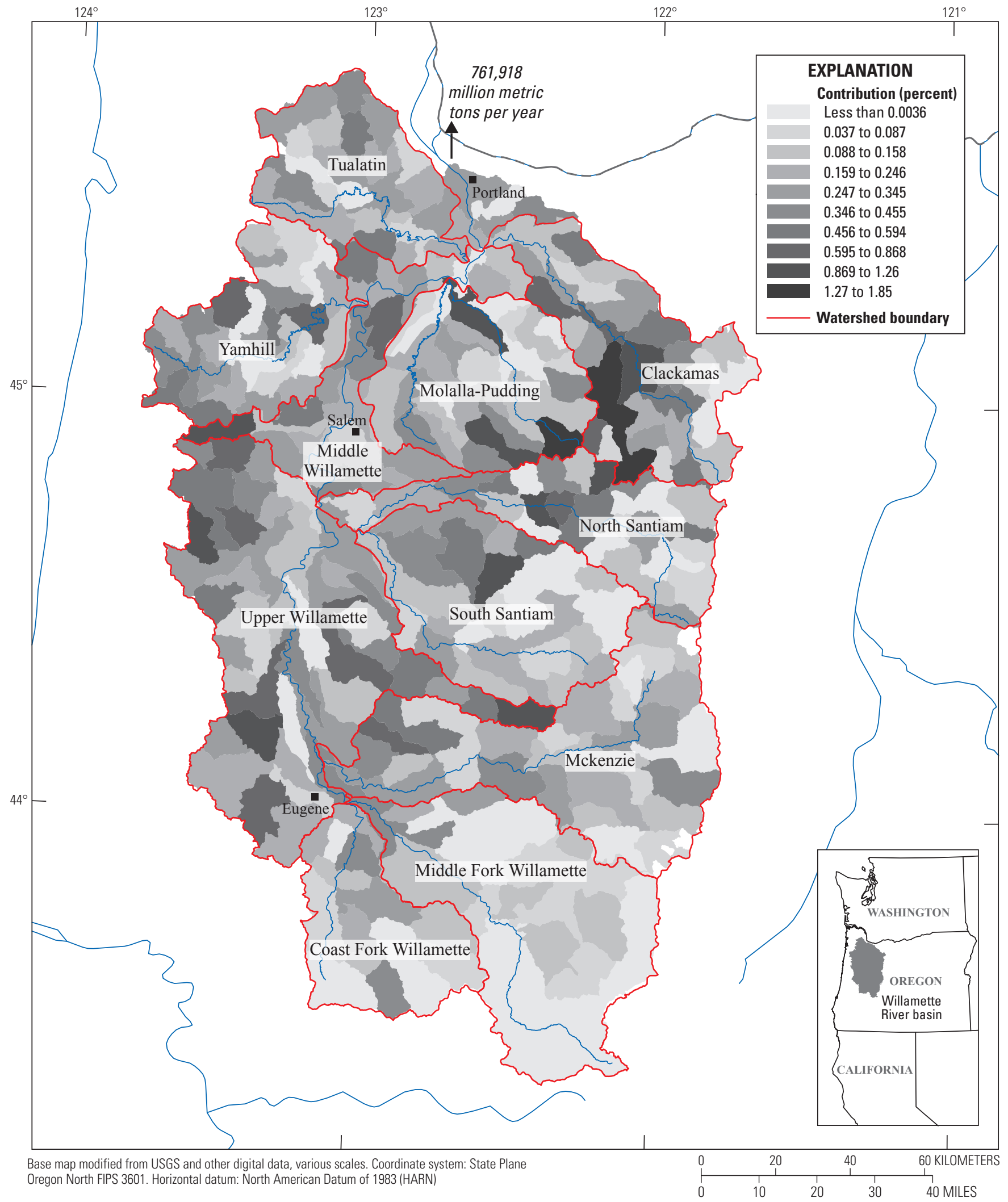

Figure 7. Contribution from selected watersheds to the estimated suspended-sediment load delivered to the Willamette River near Portland, Oregon, as predicted by the updated lithology-based suspended sediment SPARROW model for western Oregon and northwestern California. 


\section{Interpretation of Results from the Updated SPARROW Suspended Sediment Models}

The updated suspended sediment SPARROW models for western Oregon and northwestern California included explanatory variables representing generalized lithology, generalized land cover, mean annual precipitation, mean catchment slope, historical wildfire disturbance, sediment deposition in impoundments, and the difference between measured total suspended solids and suspended-sediment loads. These variables combined to provide the best fit for each of the two model configurations and both updated models provided a better fit with the measured stream loads than the original model (based on the RMSE values for the models). The relative importance of each lithologic province and land-cover class as a sediment source was a function of its estimated coefficient (which represented the mean suspended-sediment yield from that source) and its total area. Quaternary deposits, for example, covered only 17 percent of the modeling domain but contributed the most local suspended-sediment load of any lithologic province because of a relatively high model coefficient. In contrast, forest land had a much lower estimated coefficient than scrub and grass land and, as a result, contributed only 9 percent more local suspended-sediment load even though it covered 35 percent more of the modeling domain. The spatial patterns in predicted sediment yields were consistent with the patterns in lithology and precipitation. High suspended-sediment yields were predicted for the northern Oregon coastal drainages, which are mostly underlain by erodible sedimentary rocks and have high annual precipitation compared to most other areas of modeling domain. High suspended-sediment yields also were predicted for the Smith River Basin and, although this basin is mostly underlain by the relatively erosion-resistant rocks of the Klamath Terrane, it also has relatively high annual precipitation.

\section{Differences Between the Original and Updated Suspended Sediment SPARROW Models}

There were important differences between the calibration results from the original SPARROW model and the results from the updated models. Mean catchment slope and sediment loss in impoundments were significantly correlated with suspended-sediment loads in both updated models but were not in the original SPARROW model (slope was significant only when mean precipitation was not included in the original SPARROW model). Mean catchment slope was expected to be a significant explanatory variable for suspended sediment, however, and has been incorporated into many empirical models of suspended-sediment yield. For example, the U.S. Department of Agriculture Universal Soil Loss Equation incorporates slope in the calculation of the slope-steepness factor (Wischmeier and Smith, 1978). The settling and permanent removal of suspended sediment within impoundments also was expected to be a significant explanatory variable. Additional model evaluation showed that it was the inclusion of the updated hydraulic properties for the impoundments that led to catchment slope being significant in updated models; however, no apparent explanation could be determined for this result. The updated models also enabled the estimation of a coefficient to convert between the TSS loads and SSC loads used in the calibration (the estimated coefficient was equivalent to a conversion factor of slightly less than two for both models). The inclusion of this conversion term resulted in substantially greater (and presumably more accurate) estimated suspended-sediment loads throughout the modeling domain.

\section{Application of the Updated Suspended Sediment SPARROW Models}

Although the lithology- and the land-cover based models used different landscape properties to describe sediment sources, each could be useful in specific applications. For example, the updated lithology-based model provided the most accurate suspended sediment predictions and those predictions will be used to complement reach-scale bedload sediment estimates (O'Connor and others, 2014) in support of a study of larval lamprey habitat in western Oregon (Krista Jones, U.S. Geological Survey, written commun., August 21, 2018). The updated land-cover based model, however, also provided a good fit and the predictions from that model could help inform water-quality management decisions. For example, the model could allow managers to estimate how much in-stream suspended-sediment load originates in areas with extensive development (agricultural and urban land) compared to areas with relatively little human impact (forest, scrub, and grass land). The Willamette River drains a large basin consisting of various lithology and types of land cover and provides a good example of how the two SPARROW models could be used. The lithology- and land-cover based model predictions were consistent for both the total suspended-sediment load delivered to the Willamette River near its mouth and to the relative contribution from different upstream watersheds to that load; this consistency between the models supports their use as complementary tools for evaluating suspendedsediment conditions across the region. 


\section{Summary}

To further improve the understanding of the key factors affecting suspended-sediment loads in western Oregon and northwestern California a SPARROW model for suspended sediment that previously had been developed for that region was updated using some new input datasets and model software. The calibration results, mostly using the same input data as the original SPARROW model, indicated that two different but satisfactory SPARROW models were possibleone with sediment sources that were represented by local lithology and one with sediment sources that were represented by generalized land-cover classes. The lithology- and landcover based models explained about 84 and 82 percent of the variability in suspended-sediment yields, respectively. In addition to local lithology and land cover, the significant explanatory variables in both models included precipitation, catchment slope, wildfire disturbance, and sediment loss in impoundments. Other landscape characteristics (land cover, forest cover loss, canopy cover, and soil erodibility) were considered, but were not significant explanatory variables. The major differences between the updated SPARROW models and original SPARROW model were the significance of catchment slope and sediment loss in impoundments and the inclusion of a conversion term between total suspended solids and suspended-sediment-calibration loads. The effect of the conversion term was a substantial increase in the predicted reach-scale suspended-sediment yields compared to the original model.

The results showed that, even though the updated lithology- and land-cover based models used different variables to represent sediment sources, the predictions were consistent between the two models. The simulation results from both models, for example, showed that the spatial variation in lithology, land cover, and precipitation explained most of the spatial patterns in suspended sediment yields across the modeling domain. Additionally, only a small difference was indicated between the suspendedsediment loads predicted by both models near the mouth of the Willamette River, which drains a large basin of various types of land cover and lithology, and both models showed the same watersheds contributing similarly to the mean annual suspended-sediment load in that reach of the river. Both models could complement research and inform water-quality management in western Oregon and northwestern California. The land-cover based model particularly could be useful to water-quality managers because it provides estimates of how much in-stream suspended-sediment load originates in areas with extensive human impacts compared to the load that originates in areas with relatively little human impact.

\section{References Cited}

Andrews Experimental Forest, 2015, Stream chemistry concentrations and fluxes using proportional sampling in the Andrews Experimental Forest, 1968 to present: accessed June 5, 2015, at http://andrewsforest.oregonstate.edu/data/ abstract.cfm $?$ dbcode $=$ CF002\&topnav $=97$.

California Department of Water Resources, 2015, Data Library: accessed March 9, 2015, at http://www.water. ca.gov/waterdatalibrary/waterquality/index.cfm.

Gray, J.R., Glysson, G.D., Turcios, L.M., and Schwarz, S.E., 2000, Comparability of suspended sediment concentration and total suspended solids data: U.S. Geological Survey Water-Resources Investigations Report 00-4191, 14 p.

Griffiths, W.H., and Walton, B.D., 1978, The effects of sedimentation on the aquatic biota: Edmonton, Alberta, Alberta Oil Sands Environmental Research Program Report $35,86 \mathrm{p}$.

Guy, H.P., 1969, U.S. Geological Survey, Techniques of Water-Resources Investigations, Book 5, Chapter C1, 56 p., accessed April 20, 2018, at http://pubs.usgs.gov/twri/ twri5cl/html/pdf.html.

Hansen, M.C., Potopov, P.V., Moore, R., Hancher, M., Turubanova, S.A., Tyukavina, A., Thau, D., Stehman, S.V., Goetz, S.J., Loveland, T.R.A., Kommareddy, A., Egorov, A., Chini, L., Justice, C.O., and Townshend, J.R.G., 2013, High-resolution global maps of 21 st-century forest cover change: Science, v. 342, p. 850-853, accessed March 20, 2015, at http://earthenginepartners.appspot.com/science2013-global-forest.

Homer, C.H., Fry, J.A., and Barnes, C.A., 2012, The National Land Cover Database: U.S. Geological Survey Fact Sheet 2012-3020, 4 p.

Horizon Systems, 2013, NHDPlusV2Data: Horizon Systems database, accessed March 18, 2013, at http://www.horizonsystems.com/nhdplus/.

Morris, G.L., and Fan, J., 1998, Reservoir sedimentation handbook-Design and management of dams, reservoirs, and watersheds for sustainable use: New York, McGrawHill, 805 p.

O’Connor, J.E., Mangano, J.F., Anderson, S.W., Wallick, J.R., Jones, K.L., and Keith, M.K., 2014, Geologic and physiographic controls on bed-material yield, transport, and channel morphology for alluvial and bedrock rivers, western Oregon: Geological Society of America Bulletin, v. 126, no. 3-4, p. 377-397, https://doi.org/10.1130/B30831.1. 
Oregon Department of Environmental Quality, 2015a, Total maximum daily loads (TMDLs) program: Oregon Department of Environmental Quality web site, accessed August 18, 2018, at https://www.oregon.gov/deq/wq/tmdls/ Pages/default.aspx.

Oregon Department of Environmental Quality, 2015b, Laboratory Analytical Storage and Retrieval Web Application, accessed March 9, 2015, at http://deq12.deq. state.or.us/lasar2/.

Preston, S.D., Alexander, R.B., Woodside, M.D., and Hamilton, P.A., 2009, SPARROW modeling-Enhancing understanding of the Nation's water quality: U.S. Geological Survey Fact Sheet 2009-3019, 6 p.

Schwarz, G.E., Hoos, A.B., Alexander, R.B., and Smith, R.A., 2006, The SPARROW surface water-quality model-Theory, applications and user documentation: U.S. Geological Survey Techniques and Methods, book 6, chap. B3, 248 p. and CD-ROM.
Simley, J.D., and Carswell, W.J., Jr., 2009, The National Map-Hydrography: U.S. Geological Survey Fact Sheet 2009-3054, 4 p.

U.S. Geological Survey, 2015, Water-data site information for the Nation: U.S. Geological Survey database, accessed March 9, 2015, at http://waterdata.usgs.gov/nwis/si.

Wischmeier, W.H., and Smith, D.D., 1978, Predicting rainfall erosion losses-A guide to conservation planning: U.S. Department of Agriculture Agricultural Handbook No. 537, $58 \mathrm{p}$.

Wise, D.R., and O'Connor, J.E., 2016, A spatially explicit suspended-sediment load model for western Oregon: U.S. Geological Survey Scientific Investigations Report 2016-5079, 25 p., https://doi.org/10.3133/sir20165079.

Wise, D.R., 2018, Predictions from the updated SPARROW suspended sediment models developed for western Oregon and northwestern California: U.S. Geological Survey data release, https://doi.org/10.5066/P9XVX2SM. 


\section{Appendix 1. Summary of Calibration Data for the Updated Suspended Sediment SPARROW Models Developed for Western Oregon and Northwestern California}

Appendix 1 is a Microsoft Excel ${ }^{\circledR}$ file that is available for download at https://doi.org/10.3133/sir20185156. 

Publishing support provided by the U.S. Geological Survey Science Publishing Network, Tacoma Publishing Service Center

For more information concerning the research in this report, contact the Director, Oregon Water Science Center

U.S. Geological Survey

2130 SW 5th Avenue

Portland, Oregon 97201

https://www.usgs.gov/centers/or-water 
